
cited.

\title{
KEDUDUKAN PENYEWA TANAH DALAM PERJANJIAN SEWA MENYEWA TANPA JANGKA WAKTU
}

\begin{abstract}
Endang Pandamdari
(Dosen Hukum Jaminan Fakultas Hukum Universitas Tarumanagara. Meraih Sarjana Hukum pada Fakultas Hukum Universitas Indonesia (1983), Spesialis Notaris pada Fakultas Hukum Universitas Indonesia (1993), Magister Hukum pada Fakultas Hukum Universitas Indonesia

(1996), Doktor (Dr.) pada Fakultas Hukum Universitas Trisakti (2011))

(E-mail: epandamdari@yahoo.com)
\end{abstract}

\section{Aldi Pidano}

(Mahasiswa Program S1 Fakultas Hukum Universitas Tarumanagara)

Received: 22 April 2019; Accepted: 29 Mei 2019; Published: 10 Juni 2019

\begin{abstract}
In carrying out a lease agreement, Article 1570 and 1571 KUHPer regulates the termination of the lease agreement. Although the provisions regarding the existence of an element at a certain time in a lease have been strictly regulated in the KUHPer, in practice there are still many problems in the lease agreement. The problem raised by the author is how the position of the land tenant in the lease agreement without a period of time according to the Supreme Court Decision Number 534 K / PDT / 2016 and how the legal protection of landowners and tenants in the lease agreement rent without time period?. The author examines the problem by using normative legal research methods with the law approach and case approach. The research data shows that the tenant named Maman Kurniawan is not acting in good faith, namely indirectly wanting to take over ownership of other people's property and not returning the goods to others here entering into the main form of illegal acts in the form of illegally possessing objects belonging to another person and the position of Maman Kurniawan in this case is limited to tenants not owners. Then Article 1571 KUHPer is an article that protects the party who rents out in the case of land leasing agreements without a period of time and protection for tenants in the term agreement, namely requesting compensation for land and / or buildings and a certain grace period for tenants to look for other rental places.
\end{abstract}

Keywords: position, land tenant, lease agreement

\section{PENDAHULUAN}

\section{A. Latar Belakang}

Manusia sebagai makhluk sosial

manusia adalah makhluk sosial di dalam kehidupannya tidak dapat yang membutuhkan orang lain dan terlepas dari interaksi, komunikasi, dibutuhkan oleh orang lain dalam dan sosialisasi. "Disadari atau tidak kehidupan. Sebagai makhluk sosial 
Volume 17, No. 1, Juni 2019 Kedudukan Penyewa Tanah dalam Perjanjian Sewa Menyewa Tanpa Jangka Waktu

(zoon politicon), manusia dalam berinteraksi satu sama lain seringkali tidak dapat menghindari adanya bentrokan-bentrokan kepentingan (conflict of interest) di antara mereka".1)

Manusia dalam berinteraksi satu sama lain memiliki suatu tujuan yang sama yaitu memenuhi kebutuhan hidupnya. Dalam mencapai tujuan dan kebutuhan hidupnya tersebut, manusia harus bekerja sama dengan manusia lainnya untuk dapat mencapai kebutuhan hidupnya tersebut. Bentuk kerja sama antara manusia dengan manusia lainnya tersebut yaitu dengan membentuk suatu perjanjian baik lisan maupun tulisan.

Di dalam mengadakan suatu perjanjian, perjanjian dapat digolongkan menurut namanya. "Di dalam Pasal 1319 KUHPerdata dan Artikel 1355 NBW hanya disebutkan 2 (dua) macam kontrak menurut namanya, yaitu kontrak nominaat (bernama) dan kontrak innominaat (tidak bernama)". ${ }^{2)}$ Salah satu contoh

1) Bambang Sutiyoso, Metode Penelitian Hukum, cetakan ke-4, (Yogyakarta:UII Press, 2015), hal. 2.

2) Harumi Chandraresmi, "Kajian Mengenai Gugatan Melawan Hukum Terhadap Sengketa

kontrak nominaat (bernama) adalah Pasal 1548 KUHPer mengenai perjanjian sewa menyewa. Pengertian perjanjian sewa menyewa berdasarkan Pasal 1548 KUHPer yaitu "suatu persetujuan dengan mana pihak yang satu mengikatkan dirinya untuk memberikan kepada pihak yang lainnya kenikmatan dari suatu barang, selama suatu waktu tertentu dan dengan pembayaran sesuatu harga, yang oleh pihak tersebut belakangan itu disanggupi pembayarannya".

Sebagaimana pada Pasal 1549, yang menjadi obyek sewa yaitu "semua jenis barang, baik yang tak bergerak, baik yang bergerak". Pada sewa menyewa, kepemilikan sewa selalu berada di pihak yang menyewakan, pihak yang menyewakan hanya memberikan hak pemakaian atau kenikmatan atas barang tersebut dan bukan pengalihan kepemilikan barang. Sedangkan pihak penyewa sebagaimana Pasal 1560 butir 2e KUHPer wajib untuk membayar harga sewa pada waktu yang telah ditentukan kepada pihak yang menyewakan. Atas pembayaran

Wanprestasi”, Privat Law, Vol. V No.1, Januari-Juni 2017, hal. 18. 
Endang Pandamdari \& Aldi Pidan

Volume 17, No. 1, Juni 2019 Kedudukan Penyewa Tanah dalam Perjanjian Sewa Menyewa Tanpa Jangka Waktu

harga sewa, sesuai Pasal 1550 butir 3e KUHPer, pihak yang menyewakan harus memberikan kenikmatan yang tentram daripada barang yang disewakan selama berlangsungnya sewa.

Kemudian tercantum pada Pasal 1570 KUHper berbunyi “jika sewa dilakukan tersurat, sewa berakhir demi hukum, jika waktu yang ditentukan telah lewat, tanpa perlu pemberitahuan untuk itu". Dan Pasal 1571 KUHPer berbunyi bahwa "jika sewa dilakukan dengan tidak tersurat, sewa tidak berakhir pada waktu yang tidak ditentukan, jika pihak lain bahwa ia berkehendak menghentikan sewanya, dengan mengindahkan tenggang waktu yang diharuskan menurut kebiasaan setempat".

Meskipun ketentuan mengenai adanya unsur suatu waktu tertentu atau waktu sewa dalam sewa menyewa telah diatur secara tegas dalam KUHPer, namun dalam pelaksanaannya masih sangat banyak sekali terjadi permasalahan dalam perjanjian sewa menyewa, salah satunya yaitu tidak adanya jangka waktu sewa. Hukum Perjanjian memang memberikan kebebasan yang seluas-luasnya kepada masyarakat untuk mengadakan perjanjian yang berisi apa saja, asalkan tidak melanggar ketertiban umum dan kesusilaan. Akan tetapi hal tersebut akan menimbulkan pada konsekuensi gugatan hukum perdata. Seperti kasus yang penulis angkat sebagai studi kasus dalam jurnal ini dan telah diadili di Pengadilan Mahkmah Agung dengan Putusan Nomor 534 K/PDT/2016 mengenai sewa menyewa tanah yang tidak ditentukan jangka waktu di Jalan Pengukiran IV, Nomor 56, Keluarahan Desa Pekojan, Kecamatan Tambora, Jakarta Barat. Dalam kasus tersebut, Anggraini Suliarta sebagai ahli waris dari ayahnya Lie Tek Som, termohon kasasi/penggugat/terbanding yang merupakan pihak yang menyewakan dalam suatu perjanjian sewa menyewa tanah telah mengajukan gugatan perbuatan melawan hukum terhadap Maman Kurnia sebagai pemohon kasasi/tergugat/pembanding yang merupakan ahli waris dari ayahnya yang merupakan pihak penyewa terdahulu melakukan perjanjian sewa menyewa bersama pewaris pihak yang 
menyewakan dalam perjanjian tersebut.

Pada mulanya perjanjian sewa ini dilakukan oleh almarhum Lie Tek Som dengan ayah dari Maman Kurnia. Pada tanggal 12 Agustus 1959 tanah dan bangunan di Jalan Pengukiran IV, Nomor 56 Kelurahan Desa Pekojan, Kecamatan Tambora, Jakarta Barat dihibah wasiatkan dari almarhum orang tua (ayah) pihak yang menyewakan yaitu Lie Tek Som . Lalu pada tanggal 30 oktober 1986 terbit Sertipikat Hak Milik atas nama Anggraini Suliarta. Pada awalnya penyewa masih membayarkan uang kepada pihak yang menyewakan, namun dalam 6 (enam) tahun terakhir yaitu sejak tahun 2007, uang sewa tersebut tidak pernah dibayar. Lalu pihak yang menyewakan melakukan pengecekan dilapangan, tanah dan bangunan tersebut saat ini dihuni dan ditinggali oleh pihak penyewa yang sebenarnya adalah ahli waris dari ayah penyewa yang melakukan perjanjian sewa menyewa dengan ayah dari pihak yang menyewakan. Lalu pada tahun Februari 2012 pihak yang menyewakan menegur kepada penyewa untuk segera keluar meninggalkan tanah dan bangunan milik pihak yang menyewakan. Pihak penyewa berkeberatan sebab dari sejak kecil lahir sampat saat ini tinggal pada objek sengketa dan sebelumnya telah terjadi hubungan sewa menyewa dalam waktu yang cukup lama, bahkan hingga sengketa terjadi serta mengklaim sebagai pemilik bangunan seluas $100 \mathrm{~m}^{2} \mathrm{di}$ atas objek sengketa.

Berdasarkan latar belakang diatas ini, penulis tertarik untuk mengkaji lebih lanjut mengenai kedudukan penyewa tanah dalam perjanjian sewa menyewa tanpa jangka waktu dalam Putusan Mahkamah Agung Nomor 534 K/PDT/2016.

\section{B. Permasalahan}

Berdasarkan pada uraian latar belakang di atas, maka Penulis merumuskannya menjadi suatu permasalahan yang terdiri dari yaitu:

1. Bagaimana kedudukan penyewa tanah dalam perjanjian sewa menyewa tanpa jangka waktu dalam kaitan dengan pemilik tanah yang memiliki sertifikat hak 
milik menurut Putusan

Mahkamah Agung Nomor 534

K/PDT/2016?

2. Bagaimana

perlindungan

hukum terhadap pemilik tanah dan penyewa tanah dalam perjanjian sewa menyewa tanpa jangka waktu dalam kaitan dengan pemilik tanah yang memiliki sertifikat hak milik?

\section{Metode Penelitian}

Metode penelitian hukum merupakan "suatu proses untuk menemukan aturan hukum, prinsipprinsip hukum, maupun doktrindoktrin hukum guna menjawab isu hukum yang akan dihadapi". ${ }^{3)}$ Penulis di dalam penelitian menggunakan metode penelitian hukum normatif dengan pendekatan penelitian undangundang dan kasus serta sifat dari penelitian dalam penulisan ini adalah deskriptif-analitis. Di dalam penulisan ini, jenis data yang Penulis gunakan adalah jenis data sekunder dengan 2 (dua) bahan hukum yaitu primer yang terdiri dari Kitab Undang-Undang Hukum Perdata, Undang-Undang

3) Peter Mahmud Marzuki, Penelitian Hukum Edisi Revisi, (Jakarta: Kencana Prenada Media Group, 2013), hal. 3.

Nomor 5 Tahun 1960 tentang

Peraturan Dasar Pokok-Pokok

Agraria, dan Putusan Mahkamah Agung Nomor 534 K/Pdt/2016 dan Bahan hukum sekunder berupa "semua publikasi tentang hukum yang bukan merupakan dokumen-dokumen resmi". 4) serta wawancara dengan beberapa pihak yaitu hakim dan dosen. Untuk menunjang penelitian ini, Penulis juga menggunakan bahan non-hukum, yang terdiri atas "buku teks bukan hukum yang terkait dengan penelitian", 5) seperti Kamus Besar Bahasa Indonesia. Kemudian teknik pengumpulan data yang penulis gunakan adalah studi pustaka dan dengan teknis analisis data yaitu deskriptif analitis dan kualitatif dengan menggunakan suatu komponen-komponen metode kajian normatif dengan menggunakan penelitian-penelitian dengan bahan hukum kepustakaan agar dapat mengetahui dan memahami konflik permasalahan yang diteliti.

\footnotetext{
4) Ibid., hal. 181 .

5) Mukti Fajar ND dan Yulianto Achmad, Dualisme Penelitian Hukum Normatif dan Empiris, (Yogyakarta: Pustaka Belajar, 2015), hal. 43.
} 
Endang Pandamdari \& Aldi Pidano Kedudukan Penyewa Tanah dalam Perjanjian Sewa Menyewa Tanpa Jangka Waktu

\section{PEMBAHASAN}

\section{A. Perjanjian Sewa Menyewa}

Menurut Kamus Bahasa

Indonesia, Perjanjian adalah persetujuan lisan atau tersurat yang disepakati oleh kedua belah pihak atau lebih dan berjanji akan menaati apa yang tersebut dalam persetujuan itu. ${ }^{6}$ )

Di dalam Pasal 1313 KUHPerdata juga dikemukakan bahwa perjanjian adalah "suatu perbuatan dengan mana satu orang atau lebih mengikatkan dirinya terhadap satu orang atau lebih"." Perjanjian adalah "suatu hubungan hukum di bidang hukum kekayaan / harta benda antara dua pihak atau lebih, yang memberi pada satu pihak untuk memperoleh prestasi dan mewajibkan pada pihak lain untuk melakukan prestasi."

Di dalam suatu perjanjian sewa terdapat tiga unsur pokok yang harus ada didalamnya, "yang meliputi : ${ }^{9)}$

\section{Unsur Essensialia}

2. Unsur Naturalia

6) Hendi Wijaya, Kamus Bahasa Indonesia, (Jombang: Intermasa, 2003), hal. 453.

7) Harumi Chandraresmi, Op.Cit., hal. 56.

8) M. Yahya Harahap, Segi-segi Hukum Perjanjian, (Bandung: Alumni, 1986), hal. 6.

9) J. Satrio, Hukum Perjanjian, (Bandung:P.T. Citra Aditya Bakti, 1992), hal. 57-58.

\section{Unsur Accidentalia"}

Mengenai ketentuan syarat sah perjanjian, dalam Pasal 1320 KUHPer sudah diatur perbuatan apa saja yang haruus dipenuhi oleh para pihak supaya perjanjian dapaat dikatakan sah. Pasal 1320 KUHPer menssyarat sahnya perjanjian yaitu :

1. Kesepakatan yang mengikatkan diri

"Dengan sepakat dimaksudkan bahwa kedua pihak yang setuju atau seia-sekata mengenai pokokpokok dari perjanjian yang diadakan itu. Apa yang dikehendaki oleh pihak yang satu, juga dikehendaki oleh pihak yang lain.","10)

Cakapan untuk suatu perikatan

Orang yang melakukan suatu perjanjian berdasarkan hukum diharuskan cakap. Pada asasnya adalah cakap menurut hukum yaitu setiap orang yang sudah akilbaliq atau sehat pikirannya dan dewasa. Mengenai kecakapan Pasal 1329 KUHPer menyebutkan "semua orang cakap melakukan perbuatan hukum kecuali yang oleh Undang-Undang dinyatakan belum cakap."

Hal tertentu

"suatu perjanjian harus mengenai hal tertentu, artinya barang yang dimaksudkan dalam perjanjian paling sedikit harus ditentukan jenisnya."11)

Sebab halal

10) Ibid.

11) Ibid., hal. 19. 


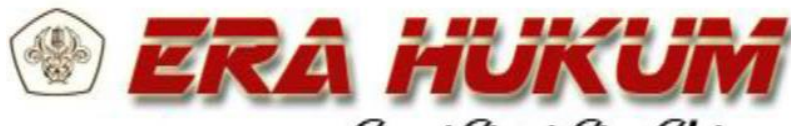 Glurnal Glmiah Glmu Glukum \\ Volume 17, No. 1, Juni 2019}

Berdasarkan ketentuan Pasal 1337 KUHPer, "suatu sebab yang diperbolehkan atau halal berarti kesepakatan yang tertuang dalam suatu perjanjian tidak boleh bertentangan dengan perundangundangan, ketertiban umum, dan kesusilaan."

Dari keempat syarat tersebut terbagi menjadi dua yaitu syarat subyektif dan syarat obyektif. Jika suatu perjanjian tidak memenuhi syarat pertama dan kedua, maka perjanjian tersebut dapat dibataalkan melalu pengadilan sedangkan jika perjanjian tersebut tidak memenuhi syarat ketiga dan eempat maka perjanjian tersebut adalah bataal demi hukum atau dianggaap tiddak pernah dilakukan perjanjian.

\section{Ketentuan}

sewa-menyewa terdapat pada dalam bab VII buuku III KUHPerdata yang judulnya "SewaMenyewa" dari Pasal 1548 hingga pasal 1600 KUHPerdata. Pengertian sewa menyewa berdasarkan Pasal 1548 KUHPerdata yaitu " persetujuan dengan mana pihak yang satu memberikan kepada pihak yang lainnya kenikmatan dari suatu barang, dengan waktu tertentu dan dengan pembayaran harga, yang disanggupi
Endang Pandamdari \& Aldi Pidano Kedudukan Penyewa Tanah dalam Perjanjian Sewa Menyewa Tanpa Jangka Waktu

pembayarannya oleh pihak tersebut belakangan itu."

Untuk menunjukkan itu merupakan perjanjian sewa menyewa maka penyewa yang diberi kenikmatan suatu barang, diwajibkan melakukan pembayaran harga untuk selama waktu tertentu kepada pemilik barang. Secara filosofi, sewa menyewa tidak berlangsung terusterusan, pada saat tertentu kenikmatan barang tersebut akan berakhir dan dikembalikan kepada pemilik karena penyewa hanya menikmati barang tersebut.

Berdasarkan uraian pengertian sewa-menyewa, dapat dipahami bahwa "unsur-unsur perjanjian sewamenyewa terdiri dari: ${ }^{12)}$

1. Sewa-menyewa adalah salah satu bentuk atau varian perjanjian;

2. Terdapat dua pihak atau lebih yang mengikatkan diri dalam perjanjian sewa-menyewa;

3. Pihak yang satu memberikan kenikmatan atas suatu barang kepada pihak yang lain, selama suatu waktu tertentu;

4. Harga sewa-menyewa yang disanggupi oleh pihak penyewa

12) Ismantoro Dwi Yuwono, Baca Buku ini Sebelum Tanda Tangan Surat Perjanjian, (Yogyakarta: Pustaka Yustisia, 2013), hal. 105. 


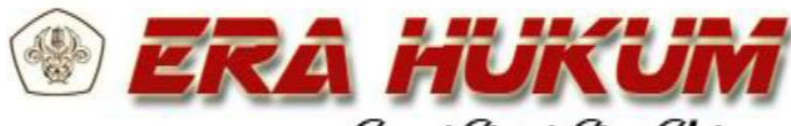 Glunal Glmiah Glmu Glukum \\ Volume 17, No. 1, Juni 2019}

atau berdasarkan kesepakatan para pihak."

\section{B. Uraian Kasus}

Pada tahun 1947 sampai dengan tahun 2013, Lie Tek Som dan ayah Maman Kurniawan telah mengadakan perjanjian sewa menyewa atas sebidang tanah beralamat di Jalan Pengukiran IV, Nomor 56, Pekojan, Tambora, Jakarta Barat untuk ditinggali dengan bukti pembayaran Ipeda/PBB dari tahun 1947.

Pada awalnya tanah tersebut masih berbentuk tanah atas dasar hak “eigendom verponding” sesuai hak eigendom verponding Nomor 12592, surat ukur nomor 17 yang terletak di Jalan Pengukiran IV Nomor 56, Jakarta Barat.

Pada tahun 1959, Tanah dan Bangunan yang berada di Jalan Pekojan IV Nomor 56 atas dasar hibah wasiat diberikan kepada Anggraini Suliarta dari almarhum orang tua (ayah) Anggraini Suliarta bernama Lie Tek Som sesuai Akta Surat Wasiat Nomor 30 tanggal 12 Agustus 1959 yang dibuat di hadapan Srie Soetengsoe Abdoel Sjoekoer, S.H., Notaris di Jakarta.
Endang Pandamdari \& Aldi Pidano Kedudukan Penyewa Tanah dalam Perjanjian Sewa Menyewa Tanpa Jangka Waktu

Pada tahun 1986, tanah hak tersebut menjadi Sertipikat Hak Guna Bangunan Nomor 1022, dan pada tahun 1986 tanah hak tersebut berubah lagi menjadi Sertipikat Hak Milik Nomor 620 tanggal 30 Oktober 1986, Gambar Situasi Nomor 76/4905/1986 tanggal 14 Oktober 1986 seluas $81 \mathrm{~m}^{2}$ atas nama Anggraini Suliarta.

Sebelum tanah dan bangunan dihibah wasiatkan kepada Anggraini Suliarta, tanah dan bangunan tersebut memang berstatus disewakan oleh almarhum ayah Anggraini Suliarta, di mana uang sewa ini awalnya masih dibayarkan kepada Anggraini Suliarta, namun dalam 6 (enam) tahun terakhir yaitu sejak tahun 2007, uang sewa tersebut sudah tidak dibayar

Berdasarkan pengecekan Anggraini Suliarta di lapangan, tanah dan bangunan tersebut saat ini dihuni dan ditinggali oleh Maman Kurniawan dan Anggraini Suliarta tidak tahu atas dasar apa Maman Kurniawan dapat menempati tanah dan bangunan milik Anggraini Suliarta tersebut.

Anggraini Suliarta melalui surat masing-masing tanggal 14 Pebruari 2012, 14 Juni 2012, dan 7 Juli 2012 sudah berulang kali 


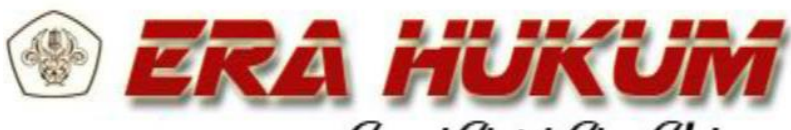 Glurnal Glmiah Glmu Glukum \\ Volume 17, No. 1, Juni 2019}

melakukan peneguran kepada Maman Kurniawan agar Maman Kurniawan segera keluar dan meninggalkan tanah dan bangunan milik Anggraini Suliarta, namun tetap saja Maman Kurniawan tidak mengindahkan teguran Anggraini Suliarta.

Anggraini Suliarta juga pernah meminta perlindungan kepada Walikota Jakarta Barat dan melalui Surat Nomor 6187/-1.711 tanggal 28 September 2012, Kantor Walikota Jakarta Barat pernah mengundang Maman Kurniawan untuk hadir di ruang rapat Asisten Pemerintahan Sekko Jakarta Barat pada tanggal 10 Oktober 2012, dimana dalam rapat walaupun Maman Kurniawan juga tidak dapat menunjukkan dasar atau hak untuk dapat menempati tanah dan bangunan milik Anggraini Suliarta, namun Maman Kurniawan tetap saja tidak mau meninggalkan dan menyerahkan tanah dan bangunan kepada Anggraini Suliarta, yang tanah dan bangunan tersebut saat ini tidak hendak Anggraini Suliarta sewakan lagi dan akan ditempati dan ditinggali sendiri oleh Anggraini Suliarta. Maman Kurniawan berkeberatan sebab dari sejak kecil lahir sampat
Endang Pandamdari \& Aldi Pidano Kedudukan Penyewa Tanah dalam Perjanjian Sewa Menyewa Tanpa Jangka Waktu

saat ini tinggal pada objek sengketa dan sebelumnya telah terjadi hubungan sewa menyewa dalam waktu yang cukup lama, bahkan hingga sengketa terjadi serta mengklaim sebagai pemilik bangunan seluas $100 \mathrm{~m}^{2}$ di atas objek sengketa.

\section{Analisa}

1. Kedudukan Penyewa Tanah dalam Perjanjian Sewa Menyewa Tanpa Jangka Waktu dalam Kaitan dengan Pemilik Tanah yang Memiliki Sertifikat Hak Milik Menurut Putusan Mahkamah Agung No. 534 K/PDT/2016

Pengertian sewa menyewa berdasarkan Pasal 1548 KUHPerdata yaitu " persetujuan dengan mana pihak yang satu memberikan kepada pihak yang lainnya kenikmatan dari suatu barang, dengan waktu tertentu dan dengan pembayaran harga, yang disanggupi pembayarannya oleh pihak tersebut belakangan itu."

Berdasarkan uraian pengertian sewa-menyewa, dapat dipahami 
Endang Pandamdari \& Aldi Pidano

bahwa "unsur-unsur perjanjian sewa-menyewa terdiri dari: ${ }^{14)}$

a. Sewa-menyewa adalah salah satu bentuk atau varian perjanjian;

b. Terdapat dua pihak atau lebih yang mengikatkan diri dalam perjanjian sewa-menyewa;

c. Pihak yang satu memberikan kenikmatan atas suatu barang kepada pihak yang lain, selama suatu waktu tertentu;

d. Harga sewa-menyewa yang disanggupi oleh pihak penyewa atau berdasarkan kesepakatan para pihak."

Untuk menunjukkan itu merupakan perjanjian sewa menyewa maka penyewa yang diberi kenikmatan suatu barang, diwajibkan melakukan pembayaran harga untuk selama waktu tertentu kepada pemilik barang. Secara filosofi, sewa menyewa tidak berlangsung terusterusan, pada saat tertentu kenikmatan barang tersebut akan berakhir dan dikembalikan kepada pemilik karena penyewa hanya menikmati barang tersebut.

${ }^{14)}$ Ismantoro Dwi Yuwono, Op.cit., hal. 105.
Pada kasus putusan Mahkamah Agung No. 534 K/PDT/2016 telah terjadi gugatan perbuatan melawan hukum yang diajukan oleh Anggraini Suliarta selaku pihak yang menyewakan dalam perjanjian sewa menyewa tanah dan bangunan di Jalan Pengukiran IV Nomor 56, Jakarta Barat terhadap Maman Kurniawan selaku pihak penyewa dalam perjanjian tersebut. Dasar diajukannya gugatan perbuatan melawan hukum tersebut adalah karena perbuatan Maman Kurniawan atau pihak penyewa dalam perjanjian tersebut telah menempati tanah dan bangunan milik Anggraini Suliarta secara tanpa hak ini jellaas merupaakan perbuuaatan melawan hukum yang menimbulkan kerugian kepada Anggraini Suliarta dimana besar kerugian yang telah ditimbulkan secara materiil yaitu sejak Tahun 2007 tidak dibayarnya uang sewa oleh Maman Kurniawan serta akibat perbuatan Maman Kurniawan yang tidak mau meninggalkan dan menyerahkan tanah dan bangunan juga telah mengganggu pikiran dan aktifitas Anggraini Suliarta. Lalu, ditemukan fakta bahwa di dalam 
Endang Pandamdari \& Aldi Pidan Kedudukan Penyewa Tanah dalam Perjanjian Sewa Menyewa Tanpa Jangka Waktu

pertimbangan putusan kasasi yaitu dalam perjanjian sewa menyewa antara Anggraini Suliarta dengan Maman Kurniawan ini tidak ditentukannya jangka waktu berakhir dengan kata lain yaitu tanpa jangka waktu.

Dalam kasus dikaitkan dengan unsur perjanjian sewa menyewa yang menjadi pihak yang menyewakan yaitu Anggraini Suliarta, yang menjadi pihak penyewa adalah Maman Kurniawan, obyek yang disewakan adalah tanah yang berada di Jalan Pengukiran IV Nomor 56, Jakarta Barat, kemudian dalam perjanjian ini tidak ditentukan jangka waktu berakhir dan pembayaran harga dari tahun 1947 namun sejak tahun 2007 Maman Kurniawan tidak membayar uang sewa.

Menurut penulis, Maman Kurniawan ini harusnya menyerahkan atau mengembalikan tanah dan bangunan kepada pemilik mengingat Secara filosofi, sewa menyewa tidak berlangsung terus-terusan, pada saat tertentu kenikmatan barang tersebut akan berakhir dan dikembalikan kepada pemilik karena penyewa hanya menikmati barang tersebut. Dengan tidak diserahkan atau dikembalikan tanah dan bangunan tersebut, ini bukan menjadi sewa menyewa akantetapi Maman Kurniawan ingin menguasai secara tidak sah barang orang lain yang merupakan perbuatan melanggar ketentuan hukum yang diatur dalam Pasal 1365 KUHPer.

\section{Pasal $1365 \quad$ KUHPer} mengatakan bahwa "setiap perbuatan melaanggar huukum, yang membawa kerugiian kepada seorang lain, mewajibkan orang yang karena salahnya mengganti kerugian tersebut". "Sesuai dengan ketentuan dalam Pasal 1365 KUHPer, maka suatu perbuatan melawan hukum haruslah mengandung unsur-unsur sebagai berikut :

a. Adanya Suatu Perbuatan;

b. Perbuatan tersebut melawan hukum; ${ }^{15)}$

c. Adanya kesalahan dari pihak pelaku;

d. Adanya kerugian bagi pihak korban;

e. Adanya hubungan kausal antara perbuatan dengan kerugian.",16)

${ }^{15)}$ Ibid., hal. 11-12. 


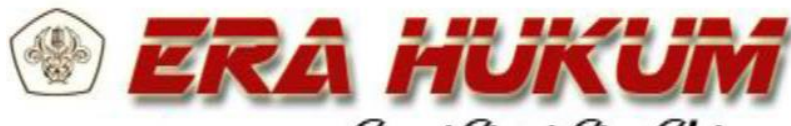 Glurnal Glmiah Glmu Glukum \\ Volume 17, No. 1, Juni 2019}

Di buku Munir Fuady diuraikan bentuk-bentuk perbuatan melawan hukum yaitu salah satunya Perbuatan melawan hukum berupa pemilikan secara tidak sah benda milik orang lain. ${ }^{17)}$

Menurut penulis, terkait perbuatan Maman Kurniawan dihubungkan dengan unsur-unsur sebagaimana Pasal 1365 KUHPer ini maka :

a. Adanya sebuah perbuatan Maman Kurniawan ini yaitu tidak mau meninggalkan dan menyerahkan tanah dan bangunan serta sejak Tahun 2007 tidak dibayarnya uang sewa oleh Maman Kurniawan, Anggraini Suliarta telah mengirimkan surat untuk menegur kepada Maman Kurniawan untuk segera keluar dan meninggalkan tanah dan bangunan milik Anggraini Suliarta sebanyak tiga kali, namun tetap saja Maman Kurniawan tidak mengindahkan teguran Anggraini Suliarta;

b. Perbuatan Maman ini sebagaimana diuraikan dalam buku Munir

16) Munir Fuady, Perbuatan Melawan Hukum Pendekatan Kontemporer, (Bandung: PT. Citra Aditya Bakti, 2002), hal. 10.

17) Ibid., hal. 67
Endang Pandamdari \& Aldi Pidano Kedudukan Penyewa Tanah dalam Perjanjian Sewa Menyewa Tanpa Jangka Waktu

Fuady yang berjudul Perbuatan Melawan Hukum Pendekatan Kontemporer adalah sesuai dengan bentuk-bentuk perbuatan melawan hukum, yaitu pertama bahwa Maman Kurniawan tidak memiliki itikad baik, kedua bahwa Maman Kurniawan tidak mau mengembalikan barang orang lain;

c. Adanya kesalahan dari pihak pelaku, disini ada unsur kesengajaan oleh Maman Kurniawan yaitu 6 tahun terakhir ia tidak membayar uang sewa padahal sebelumnya ia membayar uang sewa, serta tidak mau meninggalkan dan menyerahkan tanah dan bangunan yang padahal secara hak dimiliki oleh Anggraini Suliarta;

d. Adanya kerugian bagi pihak korban, Anggraini Suliarta mendapat kerugian yang telah ditimbulkan secara materiil yaitu sejak Tahun 2007 tidak dibayarnya uang sewa oleh Maman Kurniawan serta akibat perbuatan Maman Kurniawan yang tidak mau meninggalkan dan menyerahkan tanah dan bangunan 


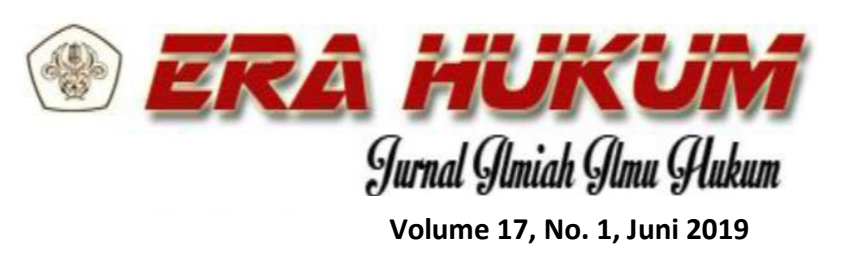

juga telah mengganggu pikiran dan aktifitas Anggraini Suliarta;

e. Adanya hubungan kausal antara perbuatan dengan kerugian, di dalam kasus ini kerugian ditimbulkan karena perbuatan Maman Kurniawan, apabila Maman Kurniawan berititkad baik maka tidak akan ada kerugian yang ditimbulkan kepada Anggraini Suliarta.

Perbuatan Maman Kurniawan ini sebagaimana diuraikan diatas telah sesuai dengan unsur perbuatan melawan hukum dengan hasil wawancara dengan Bapak Hasni yaitu mengenai apa yang sebaiknya dilakukan dan apa yang tidak lakukan. Kalau sebaiknya dilakukan dia tidak lakukan ya dia tidak beritikad baik, Apa yang sebaiknya dilakukan itu yang mesti dilakukan. Prof Abdul Gani juga membedakan perbuatan menjadi dua yaitu perbuatan dengan itikad baik dan perbuatan dengan itikad tidak baik. Menurut pendapat Prof Abdul Gani di kasus ini bahwa Maman Kurniawan ini tidak mempunyai itikad baik, apabila Maman Kurniawan mempunyai itikad baik maka dia akan berdiskusi di
Endang Pandamdari \& Aldi Pidano Kedudukan Penyewa Tanah dalam Perjanjian Sewa Menyewa Tanpa Jangka Waktu

pengadilan mengenai sewa menyewa, menanyakan kepada Anggraini Suliarta boleh tidak bahwa Maman Kurniawan ingin melanjutkan sewa menyewa dan kemungkinan Anggraini Suliarta bisa memberikan kesempatan hak kepada Maman Kurniawan untuk meneruskan sewa itu tetapi Maman Kurniawan disini tidak menunjukkan itikad baik malah melawan maka ada pernyataan melawan hukum.

Sehingga, oleh karena itu perbuatan Maman Kurniawan ini tidak beritikad baik yakni telah menempati tanah dan bangunan milik Anggraini Suliarta secara tanpa hak bahkan di dalam rekovensinya malah melawan tidak menerima bahwa tanah yang menjadi objek sengketa milik Anggraini Suliarta. Secara tidak langsung Maman Kurniawan ini mau melakukan pengambilalihan kepemilikan atas barang milik orang lain dan tidak mau mengembalikan barang kepada orang lain yang disini masuk kedalam bentuk utama dari perbuatan melawan hukum berupa pemilikan secara tidak sah benda milik orang lain.

Di dalam perjanjian sewa menyewa diatur kewajiban penyewa 


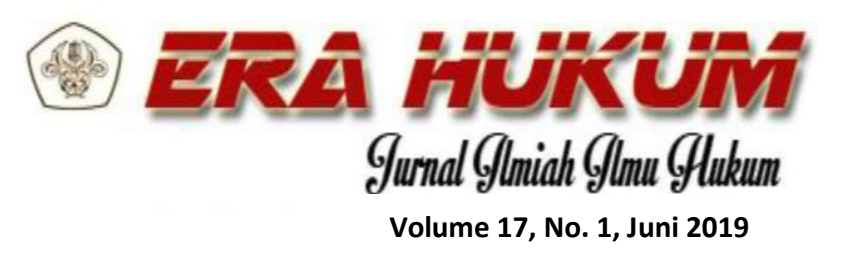

sebagaimana Pasal 1560-1566 KUHPer yang salah satunya yaitu barang sewa wajib dikembalikan oleh penyewa ketika perjanjian telah lewat waktu dan apabila tidak berakhir pada waktu yang tidak ditentukan maka berlaku Pasal 1571 KUHPer dengan mengindahkan tenggang-tenggang waktu yang diharuskan menurut kebiasaan setempat.

Dari kewajiban penyewa tersebut dapat diketahui bahwa kedudukan penyewa adalah bukan pemilik atas barang sewa dan sewa menyewa tidak berlangsung terus-terusan, pada saat tertentu kenikmatan barang tersebut akan berakhir dan dikembalikan kepada pemilik karena penyewa hanya menikmati barang tersebut. Dan dikarenakan Maman Kurniawan tidak ingin menyerahkan atau mengembalikan tanah dan bangunan tersebut, ini bukan menjadi sewa menyewa akantetapi ingin menguasai secara tidak sah barang orang lain yang merupakan perbuatan melanggar ketentuan hukum yang diatur dalam Pasal 1365 KUHPer.

Bukan hanya sesuai dengan teori perbuatan melawan hukum, kemudian didukung keterangan yang diberikan
Endang Pandamdari \& Aldi Pidano Kedudukan Penyewa Tanah dalam Perjanjian Sewa Menyewa Tanpa Jangka Waktu

oleh 3 (tiga) narasumber yang diwawancara penulis pun memiliki pendapat yang sama bahwa Maman Kurniawan ini melakukan perbuatan melawan hukum. Sehingga, patutlah kedudukan Maman Kurniawan digolongkan kedalam perbuatan melawan hukum sebagaimana yang dinyatakan dalam Pasal 1365 KUHPer yang berbunyi : “tiap perbuatan melanggar hukum, yang membawa kerugian kepada seorang lain, mewajibkan orang yang karena salahnya menerbitkan kerugian itu, mengganti kerugian tersebut".

Sehingga kedudukan Maman Kurniawan di dalam kasus ini adalah hanyalah seorang penyewa, bukan pemilik atas barang sewa dan karena ia tidak ingin mengembalikan barang milik orang lain kedudukan Maman Kurniawan di dalam Putusan Mahkamah Agung No. 534 K/PDT/2016 adalah perbuatan melawan hukum.

2. Perlindungan Hukum Terhadap Pemilik Tanah dan Penyewa Tanah Dalam Perjanjian Sewa Menyewa Tanpa Jangka Waktu Dalam Kaitan Dengan Pemilik 


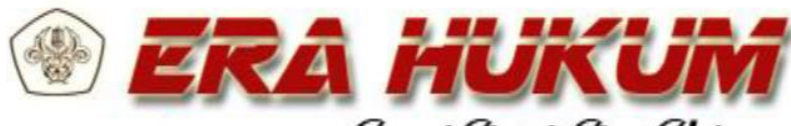 Glurnal Glmiah Glmu Glukum \\ Volume 17, No. 1, Juni 2019}

Endang Pandamdari \& Aldi Pidano Kedudukan Penyewa Tanah dalam Perjanjian Sewa Menyewa Tanpa Jangka Waktu
Tanah yang Memiliki Sertifikat Hak Milik

Tujuan pokok dari hukum adalah "menciptakan tatanan masyarakat yang tertib, menciptakan ketertiban dan keseimbangan. Dengan tercapainya ketertiban di dalam masyarakat diharapakan kepentingan masyarakat akan dapat terlindungi. Untuk mencapai tujuan hukum tersebut, hukum harus mampu membagi mana yang menjadi hak dan mana yang menjadi kewajiban warga masyarakat, membagi wewenang, dan mengatur cara menyelesaikan masalah hukum serta memelihara kepastian hukum."20)

\section{Sebagaimana}

tercantum tercantum pada Pasal 1570 KUHper berbunyi “jika sewa dilakukan tersurat, sewa berakhir demi hukum, jika waktu yang ditentukan telah lewat, tanpa perlu pemberitahuan untuk itu". Dan Pasal 1571 KUHPer berbunyi bahwa "jika sewa dilakukan dengan tidak tersurat, sewa tidak berakhir pada waktu yang tidak ditentukan, jika pihak lain bahwa ia berkehendak menghentikan sewanya,

20) R.M. Sudikno Mertokusumo, Hukum dan Politik Agraria, (Jakarta: Karunika, 1998), hal.77. dengan mengindahkan tenggang waktu yang diharuskan menurut kebiasaan setempat".

Dalam kasus perjanjian sewa menyewa tanah antara Anggraini Suliarta dengan Maman Kurniawan, bahwa patut dan adil sewa menyewa berakhir jika Anggraini Suliarta mengakhiri sewa menyewa karena ingin menikmati sendiri tanah yang dimiliki Anggraini Suliarta sendiri walaupun tidak ditentukan jangka waktu berakhir. Oleh karena itu, maka berlakulah Pasal 1571 KUHPer. Karena tidak ditentukan jangka waktu berakhir maka terkait persoalan tersebut adalah mengacu kepada undang-undang. Dengan demikian, Anggraini Suliarta berhak atas objek sewa itu dan hendak menghentikan sewa itu karena ingin dinikmati sendiri oleh Anggraini Suliarta.

Namun, dalam kenyataannya Maman Kurniawan bersikukuh sebab dari sejak kecil lahir sampat saat ini tinggal pada objek sengketa dan sebelumnya telah terjadi hubungan sewa menyewa dalam waktu yang cukup lama, bahkan hingga sengketa terjadi serta mengklaim sebagai pemilik bangunan seluas $100 \mathrm{~m}^{2} \mathrm{di}$ 
Endang Pandamdari \& Aldi Pidano Kedudukan Penyewa Tanah dalam Perjanjian Sewa Menyewa Tanpa Jangka Waktu

atas objek sengketa. Terkait perbuatan Maman Kurniawan, Anggraini Suliarta telah mengirimkan surat sebanyak tiga kali untuk menegur kepada Maman Kurniawan serta telah meminta perlindungan hukum kepada Walikota Jakarta Barat agar Maman Kurniawan segera keluar dan meninggalkan tanah dan bangunan milik Anggraini Suliarta, namun tetap saja Maman Kurniawan tidak mengindahkan teguran Anggraini Suliarta

Menurut penulis, Maman Kurniawan telah melakukan perbuatan mewan hukum, Maman Kurniawan telah melakukan perbuatan melawan hukum karena tidak mengindahkan teguran Anggraini Suliarta yang merupakan pemilik sah atas tanah tersebut. perjanjian sewa menyewa sesuai Pasal 1548 KUHPer hanya memberikan kepada pihak yang lainnya kenikmatan dari suatu barang, selama suatu waktu tertentu dan dengan pembayaran sesuatu harga, yang oleh pihak tersebut belakangan itu disanggupi pembayarannya dan bukan berarti pihak lainnya yaitu penyewa dapat menguasai objek dari sewa menyewa, meskipun sesuai kesepakatan dengan landasan hukum Pasal 1320 KUHPer apabila sudah lama harus balik ke pemilik apabila tidak mau diperpanjang oleh pemilik.

Kemudian terkait perbuatan Maman Kurniawan yang bersikukuh bahwa sejak kecil lahir sampat saat ini tinggal pada objek sengketa dan sebelumnya telah terjadi hubungan sewa menyewa dalam waktu yang cukup lama, bahkan hingga sengketa terjadi serta mengklaim sebagai pemilik bangunan seluas $100 \mathrm{~m}^{2} \mathrm{di}$ atas objek sengketa adalah itikad tidak baik.

Menurut Penulis, Maman Kurniawan seharusnya beritikad baik musyawarah mengenai perjanjian sewa menyewa tersebut. Memang perjanjian tersebut pada awalnya adalah berasal dari orang tuanya namun Pasal 1575 KUHPer mengatakan perjanjian sewa tidak sekali-kali hapus dengan meninggalnya pihak yang menyewakan, maupun dengan meninggalnya pihak yang menyewa.

Sehingga perlindungan hukum untuk pihak yang menyewakan yaitu dengan menggunakan Pasal 1571 bahwa meskipun tidak ditentukan 
Endang Pandamdari \& Aldi Pidan

Volume 17, No. 1, Juni 2019 Kedudukan Penyewa Tanah dalam Perjanjian Sewa Menyewa Tanpa Jangka Waktu

jangka waktu berakhir, pihak yang menyewakan bebas untuk menghentikan kapan saja tetapi dengan mengindahkan tenggangtenggang waktu dan perlindungan hukum untuk penyewa yang beritikad baik yaitu pihak penyewa bisa melakukan mediasi untuk agar terus dapat melanjutkan sewa dan/atau mendapatkan ganti kerugian atas tanah dan/atau bangunan dan masa tenggang tertentu bagi penyewa untuk mencari tempat sewa lainnya.

\section{III.PENUTUP}

\section{A. Kesimpulan}

Berdasarkan penelitian yang telah penulis lakukan baik studi kepustakaan maupun wawancara yang ada dalam uraian bab-bab sebelumnya tentang perbuatan melawan hukum dan perjanjian sewa menyewa, maka dapat ditarik kesimpulan sebagai berikut:

1. Perbuatan yang dilakukan oleh Maman Kurniawan sebagai pihak penyewa dalam kasus putusan Mahkamah Agung No. 534 K/PDT/2016 yaitu tidak ingin menyerahkan atau mengembalikan tanah dan bangunan yang berada di

Jalan Pengukiran IV Nomor 56 adalah merupakan perbuatan melawan hukum dan tidak dapat dibenarkan.

Maman Kurniawan seharusnya menyerahkan atau mengembalikan tanah dan bangunan kepada pemilik yaitu Anggraini Suliarta. Di dalam perjanjian sewa menyewa, sebagaimana Pasal 1560-1566 KUHPer diatur kewajiban penyewa yang salah satunya yaitu penyewa berkewajiban membalikkan barang yang disewa seperti sediakala ketika perjanjian sewa menyewa tersebut telah habis waktunya dan tidak ditentukan jangka waktu maka berlaku Pasal 1571 KUHPer dimana jika pihak lain bahwa ia hendak menghentikan sewanya, dengan mengindahkan tenggangtenggang waktu yang diharuskan menurut kebiasaan setempat. mengingat hak milik atas barang tersebut tetap berada dalam tangan pemilik semula. Dengan tidak diserahkan atau dikembalikan tanah dan bangunan tersebut, ini bukan menjadi sewa menyewa akantetapi Maman Kurniawan ingin menguasai secara tidak sah barang 
Endang Pandamdari \& Aldi Pidano Kedudukan Penyewa Tanah dalam Perjanjian Sewa Menyewa Tanpa Jangka Waktu

orang lain yang merupakan perbuatan melanggar ketentuan hukum yang diatur dalam Pasal 1365 KUHPer.Sehingga dapat disimpulkan bahwa kedudukan seorang penyewa yaitu bukan pemilik atas obyek sewa dan pada saat jangka waktu berakhir, obyek wajib dikembalikan kepada pemilik semula serta kedudukan Maman Kurniawan di dalam Putusan Mahkamah Agung No. 534 K/PDT/2016 disini adalah melakukan perbuatan melawan hukum, terlebih telah keluarnya putusan pengadilan yang telah mempunyai kekuatan hukum tetap. karena ia tidak ingin mengembalikan barang milik orang lain.

2. Pasal 1571 KUHPer yang berbunyi bahwa jika sewa tidak dibuat dengan tersurat, maka sewa itu tidak berakhir pada waktu yang tidak ditentukan, melainkan jika pihak lain bahwa ia hendak menghentikan sewanya, dengan mengindahkan tenggang-tenggang waktu yang diharuskan menurut kebiasaan setempat.
Perjanjian sewa menyewa tidak menghilangkan hak si pemilik atas tanah. Saat pemilik yuridis hak atas tanah menyampaikan niatnya untuk menempati tanah maka pada tahun tersebut masa sewa berakhir dengan masa tenggang tertentu sewajarnya bagi penyewa untuk mencari tempat sewa lainnya. Hukum hak milik pemilik tanah tetap melekat terus, rumahnya kemanapun pergi tidak bermasalah tetapi saat pihak yang menyewakan perlukan dapat digugat pengadilan karena sewa menyewa tanpa jangka waktu tidak bisa diputuskan begitu saja dimana banyak pihak yang tidak beritikad baik dengan niat untuk menguasai tanah dan bangunan seakan-akan pemilik. Pihak yang menyewakan harus mengutarakan gugatan pengadilan agar memberikan legitimasi hukum dan mempunyai legal standing.

Dan untuk pihak penyewa yang khususnya sebagai pihak yang berperkara dalam putusan Mahkamah Agung No. 534 K/PDT/2016 yaitu Maman Kurniawan dapat ditarik kesimpulan harus beritikad baik 
Endang Pandamdari \& Aldi Pidan

dalam melakukan perjanjian sewa menyewa baik dengan jangka waktu maupun tanpa jangka waktu. Pihak yang beritikad baik dipastikan mendapat perlindungan hukum dan apabila tidak beritikad baik pasti dikalahkan di pengadilan. Dapat diambil Kesimpulan yaitu perlindungan hukum bagi pihak yang menyewakan yaitu dengan menggunakan Pasal 1571 bahwa meskipun tidak ditentukan jangka waktu berakhir, pihak yang menyewakan bebas untuk menghentikan kapan saja tetapi dengan mengindahkan tenggangtenggang waktu dan perlindungan hukum untuk penyewa yang beritikad baik yaitu pihak penyewa bisa melakukan mediasi untuk agar terus dapat melanjutkan sewa dan/atau mendapatkan ganti kerugian atas tanah dan/atau bangunan dan masa tenggang tertentu bagi penyewa untuk mencari tempat sewa lainnya.

\section{B. Saran}

Mengenai permasalahan yang penulis angkat ke dalam penulisan ini, penulisan ingin memberikan saran:

1. Saran yang ditujukan terhadap para pihak dalam kasus yang diangkat penulis dalam penulisan ini :

Apabila terjadi konflik di antara para pihak dalam suatu perjanjian mengenai suatu perihal yang tidak diatur dalam perjanjian hendaknya diselesaikan terlebih dahulu dengan cara musyawarah. Kedua belah pihak pun harus beritikad baik. apa yang sebaiknya dilakukan dan apa yang tidak baik jangan dilakukan. Dalam perjanjian sewa menyewa, bila tidak diatur jangka waktu pihak penyewa pun jangan ada niat untuk menguasai tanah dan bangunan seakan-akan pemilik.

Penyewa di dalam perjanjian sewa menyewa hanya menikmati kenikmatan atas suatu benda. Jika pihak penyewa sudah beritikad baik, pihak yang menyewakan harus memberikan kesempatan kepada pihak penyewa untuk melanjutkan sewanya. Bila pihak 


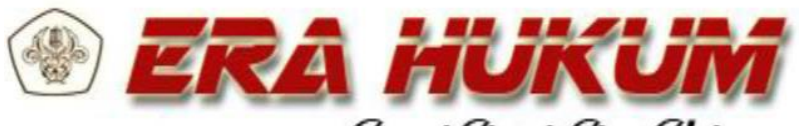 Glurnal Glmiah Glmu Glukum \\ Volume 17, No. 1, Juni 2019}

yang menyewakan tetap tidak ingin dilanjutkan sewa menyewa maka beri ganti kerugian kepada pihak penyewa atas bangunan yang ia bangun diatas tanah tersebut serta pihak yang menyewakan jangan langsung bertindak menghentikan perjanjian sewa menyewa secara sepihak lalu meminta penyewa mengosongkan rumah. Perjanjian sewa menyewa yang waktu tidak ditentukan haruslah berakhir dengan tenggang waaktu yang diwajibkan berdasar kebiasaan setempat. Beri waktu penyewa untuk mencari tempat sewa baru atau kesepakatan bersama kedua belah pihak.

2. Saran yang ditujukan kepada setiap subjek hukum yang ingin mengadakan perjanjian sewa menyewa. Dalam hal para pihak ingin mengadakan perjanjian sewa menyewa baik dengan jangka waktu maupun tanpa jangka waktu haruslah diperhatikan sebaik mungkin unsur-unsur dalam perjanjian sewa menyewaIV. Perjanjian harus dibuat serinci mungkin dan dibaca dengan teliti karena perjanjian merupakan alat
Endang Pandamdari \& Aldi Pidano Kedudukan Penyewa Tanah dalam Perjanjian Sewa Menyewa Tanpa Jangka Waktu

bukti di kemudian hari yang memiliki kekuatan hukum apabila terjadi sengketa di pengadilan. Suatu perjanjian sewa yang baik adalah perjanjian yang mengatur semua hal-hal yang penting atau hal-hal yang seharusnya diatur, seperti jangka waktu, tata cara pembayaran, peangkhiran perjanjian, dan lain-lain. Kemudian untuk perihal jangka waktu, untuk mengantisipasi muncul hal-hal yang tidak diingkan di kemudian hari dan melawan penafsiran dan keterangan ganda maka penempatan waktu jelas sangat diperlukan serta kerjakan secara tersurat. Jika perjanjian sewa menyewa tidak dikerjakan rinci dan tidak tersurat tentunya akan menjadi sulit dikemudian hari dan akhirnya para pihak menghabiskan biaya dan waktu untuk menyelesaikan permasalahan tersebut melalui pengadilan.

\section{DAFTAR PUSTAKA}

\section{A. Buku}

Fuady, Munir. Perbuatan Melawan Hukum Pendekatan 
Kontemporer. Bandung: (Juni 2017):1-61. Diakses PT Citra Aditya, 2002.

Harahap, M. Yahya. Segi-Segi

Hukum Perjanjian.

Bandung: Alumni, 1986.

Marzuki, Peter Mahmud.

Penelitian Hukum Edisi

Revisi. Jakarta: Kencana

Prenada Media Group, 2013.

Mertokusumo, R.M. Sudikno.

Hukum dan Politik

Agraria. Jakarta:

Karunika, 1998.

ND, Mukti Fajar dan Yulianto

Achmad. Dualisme

Penelitian Hukum

Normatif dan Empiris.

Yogyakarta: Pustaka

Belajar, 2015.

Satrio, J. Hukum Perjanjian.

Bandung: P.T Citra

Aditya Bakti, 1992.

Sutiyoso, Bambang. Metode

Penelitian Hukum.

Cetakan ke-4.

Yogyakarta: UII Press,

2015.

Yuwono, Ismantoro Dwi. Baca

Buku ini Sebelum Tanda

Tangan Surat Perjanjian.

Yogyakarta: Pustaka

Yustisia, 2013.

Wijaya, Hendi. Kamus Bahasa

Indonesia. Jombang:

Intermasa, 2003.

B. Artikel Jurnal Online

Chandraresmi, Harumi. "Kajian

Mengenai Gugatan

Melawan Hukum

Terhadap Sengketa

Wanprestasi”. Privat

Law. Volume 5, Nomor 1 